\title{
Komunikasi Keluarga dan Resiliensi pada Perempuan Korban Kekerasan Berbasis Gender Online
}

\section{Family Communication and Resilience on Women Victims of Online Gender-Based Violance}

\author{
Sri Mustika ${ }^{1, *)}$, Tellys Corliana
}

${ }^{1}$ Universitas Muhammadiyah Prof. Dr. Hamka, J1. Limau II, Kebayoran Baru, DKI Jakarta 12210, Indonesia

*) E-mail korespondensi: srimustika@uhamka.ac.id

Diterima: 9 Des 2021 | Disetujui: 26 Jan 2022 | Publikasi online: 4 Februari 2022

\section{ABSTRACT}

The virtual world is not a safe place for women. Many women are victims of online gender-based violence (KBGO). This study aims to examine family communication, resilience, and KBGO victims. Researchers used a qualitative approach with a descriptive type. Participants in this study amounted to five people. These five informants were chosen purposively. Data was collected by observation, in-depth interviews, and literature study. Data analysis was carried out using the Miles and Huberman model. This research was conducted in Jakarta and its surroundings from February to August 2021. Researchers found that the victims of KBGO were women who were active on social media, including Twitter, Facebook, and Instagram. Not all victims of violence know the perpetrators, although some recognized the perpetrators as close people, such as friends from a community and siri's ex-husband. Not all victims have the courage to share their problems with their families. The pattern of family communication also determines the victim's openness to her family. Likewise, the resilience of the victim in dealing with this case is closely related to the communication pattern of her family. Victims who have consensual communication patterns have resilience and managed to get through the case well. However, the support of friends can help the victim in overcoming the problem.

Kata kunci: level of resilience, pattern of family communication, online gender-biased violence, social media

\section{ABSTRAK}

Dunia maya ternyata bukan tempat yang aman bagi perempuan. Dalam dunia tersebut, perempuan banyak menjadi korban kekerasan berbasis gender online (KBGO). Penelitian ini bertujuan mengkaji tentang komunikasi keluarga, resiliensi, dan korban KBGO. Peneliti menggunakan pendekatan kualitatif dengan jenis deskriptif. Partisipan dalam penelitian ini berjumlah lima orang. Kelima informan ini dipilih secara sengaja (purposive). Pengumpulan data dilakukan dengan pengamatan, wawancara mendalam, dan studi pustaka. Analisis data dilakukan dengan menggunakan model Miles dan Huberman. Penelitian ini diadakan di Jabodetabek sejak Februari hingga Agustus 2021. Peneliti menemukan bahwa korban KBGO adalah para perempuan yang aktif di media sosial, baik Twitter, Facebook, dan Instagram. Tidak semua korban kekerasan mengetahui pelakunya, meski ada yang mengenali pelakunya adalah orang dekat, seperti teman satu komunitas dan mantan suami siri. Tidak semua korban berani mengisahkan masalahnya pada keluarga. Pola komunikasi keluarga ikut menentukan keterbukaan korban terhadap keluarganya. Demikian pula resiliensi korban dalam menghadapi kasus ini berkaitan erat dengan pola komunikasi keluarganya. Korban yang memiliki pola komunikasi konsensual memiliki resiliensi dan berhasil melewati kasusnya dengan baik. Meskipun demikian dukungan teman dapat membantu korban dalam mengatasi masalahnya.

Kata kunci: level resiliensi, pola komunikasi keluarga, kekerasan berbasis gender online, media sosial

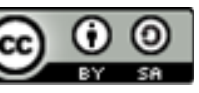

Content from this work may be used under the terms of theCreative Commons Attribution-ShareAlike 4.0

International. Any further distributionof this work must maintain attribution to the author(s) and the title of the work, journal citation and DOI.

Published under Department of Communication and Community Development Science, IPB University and in association with Forum Komunikasi Pembangunan Indonesia and Asosiasi Penerbitan Jurnal Komunikasi Indonesia.

E-ISSN: 2442-4102 | P-ISSN: 1693-3699 


\section{PENDAHULUAN}

Setelah ada teknologi Internet kini dunia menjadi lebih mudah terhubung dan informasi dapat tersebar dengan cepat. Internet bukan sekadar alat tetapi memberikan manfaat bagi tumbuhnya ikatan sosial di Internet, nilai-nilai dalam masyarakat virtual hingga pada struktur sosial secara daring. Castells (Nasrullah, 2018) mengatakan, jaringan adalah pesan, sedangkan Internet merupakan pembawa pesan (messenger).

Di Indonesia pengguna Internet mencapai 175,4 juta dan pengguna media sosial aktif sebanyak 160 juta (Riyanto, 2020). Data statistika mencatat pengguna media sosial berusia 25-34 tahun berjenis kelamin laki-laki berjumlah 20,6\% dan perempuan berjumlah 14,8 \% (Statistika, 2020). Pengguna media sosial berusia 18-24 tahun berjenis kelamin laki-laki $(16,1 \%)$ dan perempuan $(14,2 \%)$. Dengan jumlah pengguna internet dan media sosial sebanyak itu, maka lalu lintas pesan sangat penuh sesak. Di satu sisi kenyataan ini menggembirakan. Namun, di sisi lain juga mencemaskan karena di internet orang mudah kehilangan data pribadi dan privasinya. Hal ini disebabkan belum adanya jaminan keamanan data diri pengguna di media digital. Ketika hampir semua orang dapat terhubung dengan Internet dan memiliki akun di media sosial, seperti Twitter, Facebook, dan Instagram perempuan justru banyak yang mengalami kekerasan berbasis gender online (KBGO).

KBGO adalah segala bentuk tindakan yang membuat seseorang tidak aman atau merasa tidak aman, menyerang gender atau seksualitas gender atau seksualitas seseorang, dan difasilitasi oleh Internet serta teknologi. KBGO merupakan pelanggaran privasi, karena pelaku bertindak tanpa persetujuan korban (SAFEnet, 2019).

Plan International melakukan survei pada 2020 dan menemukan bahwa dari 14.000 responden perempuan, $58 \%$ orang mengaku pernah mengalami kekerasan daring, termasuk bahasa yang kasar dan periksakan siber (cyberbullying). Riset yang diadakan World Association of Girl Guides dan Girl Scout menemukan bahwa $84 \%$ responden berpikir bahwa saat ini masalah KBGO memburuk (Web Foundation, 2021).

Di Indonesia, KBGO juga sudah banyak terjadi. Lembaga Bantuan Hukum Asosiasi Perempuan Indonesia untuk Keadilan (LBH APIK) mencatat adanya 659 kasus KBGO (Al-Ubaidah, 2021). Jumlah ini meningkat drastis dibandingkan dengan tahun 2017 (16 kasus), 2018 (97 kasus), dan 2019 (281 kasus). Dari data tersebut, tampak bahwa KBGO merupakan masalah yang dialami oleh perempuan pengguna media sosial di banyak tempat dan di berbagai lingkungan sosial. Kasus KBGO paling banyak terjadi pada media sosial, seperti Facebook (FB), Instagram (IG), dan Whattsap (WA). Bentuk kekerasannya beragam, misalnya pelecehan seks daring dengan kekerasan verbal, online grooming (proses meyakinkan korban melalui media sosial untuk melakukan hal-hal cabul yang diperintahkan pelaku), ancaman akan menyebarkan foto/video asusila (Hayati, 2021).

(Putri, 2020) menemukan jenis-jenis KBGO dikalangan mahasiswa Universitas Pendidikan Indonesia meliputi sexting, impersonation, cyber recruitment, cyber harassment/stalking, dan revenge porn. Adapun faktor-faktor pendorongnya, secara internal adalah dorongan hasrat seksual dari pelaku, balas dendam, dan rasa cemburu pelaku terhadap korban, serta kebutuhan keuangan pelaku. Dari faktor eksternal penyebabnya adalah budaya patriarki yang menghasilkan stereotip gender dan menganggap perempuan sebagai pihak yang lemah, perlunya penegakan hukum terhadap kekerasan seksual secara umum dan kekerasan berbasis gender online secara khusus, masih rendahnya kesadaran terhadap hukum dan kemudahan mengakses media sosial.

Permasalahan gender masih belum tuntas, baik itu di Indonesia maupun di dunia internasional. Gender merupakan jenis kelamin sosial, di mana peran laki-laki dan perempuan dikonstruksikan baik secara sosial maupun budaya. Konsep gender merupakan konstruksi sosial, sehingga perbedaan-perbedaan jenis kelamin tidak perlu menyebabkan perbedaan peran dan perilaku gender dalam tatanan sosial (Hubeis \& Mulyandari, 2010). Namun permasalahan gender ini sangat berkaitan dengan ideologi patriarkhi yang memunculkan konsep dominasi laki-laki terhadap perempuan sebagai kondisi yang wajar. Kewajaran ini memunculkan narasi bahwa perempuan merupakan mahluk yang lemah, inferior, sehingga harus menuruti segala kehendak laki-laki. Penolakan akan berakhir dengan tindak kekerasan. Inilah yang kemudian dikatakan sebagai kekerasan berbasis gender.

Kekerasan berbasis gender merupakan kekerasan yang mencerminkan adanya relasi kuasa yang tidak seimbang antara laki-laki dan perempuan serta melanggengkan subordinasi perempuan sebagai lawan laki-laki. Dalam kerangka patriarkhi kekerasan ini merupakan sistem simbolik yang melahirkan 
serangkaian praktik sehari-hari yang menyangkal hak-hak perempuan dan mereproduksi ketidakseimbangan dan keteidaksetaraan yang ada di antara kedua jenis kelamin (Risya et al., 2021).

Kekerasan terhadap perempuan berbasis gender ini dapat dikatakan sebagai permasalahan global, karena terjadi hampir di setiap negara. Strategi penanggulangannya sangat ditentukan oleh kebijakan masing-masing negara. Di Swedia, misalnya, pencegahan terhadap kekerasan ini menjadi kebijakan pemerintah di tingkat lokal dan regional. Meskipun pada praktiknya banyak menghadapi hambatan, seperti pemahaman tentang gender dan kekerasan pada masyarakat, disamping kurangnya dialog secara bottom up (Nyhlén \& Nygren, 2019).

Kondisi pandemi yang mengharuskan masyarakat untuk tinggal di rumah ternyata juga meningkatkan kasus kekerasan terhadap perempuan hampir di semua negara. Hal ini memunculkan kebijakan di berbagai negara tentang kekerasan terhadap perempuan di masa pandemi. Di Inggris, misalnya, di masa lock down awal pemerintah sudah menyadari adanya kemungkinan peningkatan kasus kekerasan, sehingga mereka berkomitmen untuk memberikan bantuan finansial terhadap penyintas kekerasan dalam rumah tangga (Gunby et al., 2020).

Di Indonesia, kesadaran akan semakin meningkatnya kekerasan di masa pandemi dan keterbatasan para sukarelawan akibat kebijakan lock down di berbagai wilayah mendorong dibentuknya Panduan Perlindungan Hak Perempuan dari Diskriminasi dan Kekerasan Berbasis Gender (KBG). Panduan ini merupakan panduan lintas kementerian/lembaga, organisasi pemerintah daerah, dan penyelenggara program dan layanan terhadap perempuan. Dengan demikian dapat dipastikan hal-hal seperti pencegahan dan penanganan perempuan dari stigma, diskriminasi, dan KBG akibat pandemi; Pemenuhan hak (kebenaran, keadilan, keamanan dan pemulihan, baik medis maupun psikososial, serta pemberdayaan ekonomi) penyintas KBG dalam situasi pandemi; Pencegahan atau mengurangi keterpisahan perempuan dengan anak atau pengasuhnya di situasi pandemi; dan pendokumentasian, rujukan, dan pemantauan kasus-kasus terkait diskriminasi dan kekerasan pada perempuan (Kemen PPPA RI, 2020).

Dalam perkembangannya, kekerasan terhadap perempuan tidak hanya terjadi dikehidupan nyata, tetapi juga merambah ke dunia daring (online). Karena itu, kekerasan di sini disebut sebagai Kekerasan Berbasis Gender Online (KBGO). Berkaitan dengan hal ini Kementerian Pemberdayaan Perempuan dan Perlindungan Anak (Kemen PPPA) mendorong peningkatan literasi digital bagi perempuan sebagai upaya pencegahan KBGO. Hal ini disebabkan semasa pandemi semua aktivitas masyarakat beralih ke digital, sehingga kekerasan terhadap perempuan pun menjadi kekerasan berbasis gender online.

Berbeda dengan kasus kekerasan pada umumnya yang pelakunya lebih mudah teridentifikasi, pelaku KBGO sulit didentifikasi, sedangkan jejak digital korban yang terlanjur tersebar di Internet sulit dihapus. Hal ini menjadi permasalahan tersendiri bagi korban KBGO (Kemen PPPA RI, 2021).

(Hikmawati, 2021) dalam penelitiannya berjudul Pengaturan Kekerasan Berbasis Gender Online menemukan bahwa kasus KBGO dengan menggunakan UU No. 11 Tahun 2008 tentang Informasi dan Transaksi Elektornika dan atau UU No. 44 Tahun 2008 Tentang Pornografi menimbulkan multitafsir dalam penerapannya. Korban justru dapat dijadikan tersangka. Hal ini menimbulkan ketidakpastian hukum dan ketidakadilan bagi korban. Selain itu, Rencana Undang-Undang Prioritas Penghapusan Kekerasan Seksual (RUUP PKS) meskipun memuat tentang berbagai jenis kekerasan seksual, namun di dalamnya belum memuat tentang KBGO secara eksplisit.

Studi lain tentang KBGO dilakukan oleh (N. Sari, 2021) yang mengkaji tentang komunikasi keluarga, resiliensi, dan korban Kekerasan Berbasis Gender Online (KBGO). Dalam menghadapi kasus KBGO, peran komunikasi keluarga dan resiliensi memiliki peran yang penting. Psikolog Paul Watzlawick (Littlejohn \& Foss, 2016) menyatakan aksioma bahwa manusia tidak dapat tidak berkomunikasi. Walaupun dalam keadaan diam manusia tetap berkomunikasi, karena sebetulnya ia menyampaikan pesannya secara nonverbal. Dalam kehidupan manusia yang merupakan makhluk sosial komunikasi menjadi unsur yang penting. Melalui komunikasi, manusia dapat menyampaikan keinginan, pesan, dan tujuan- tujuan lainnya. Dalam konteks keluarga, komunikasi merupakan satu aspek penting agar anggotanya satu sama lain dapat saling memahami dan menyayangi.

Pada dasarnya komunikasi keluarga merupakan cara untuk memahami keluarga dan membina relasi di dalamnya. Sedikitnya ada tiga alasan yang dikemukan para ahli tentang fokus kajian komunikasi keluarga. Dalam Handbook of Family Communication (Vangelisti, 2004) dijelaskan bahwa pertama, keluarga merupakan mekanisme untuk sosialisasi pengalaman yang paling awal. Dengan mengamati 
dan berinteraksi dengan anggota keluarga kebanyakan orang belajar berkomunikasi dan yang lebih penting ketika mereka belajar untuk memikirkan komunikasi. Kedua, komunikasi adalah sarana anggota keluarga untuk menjalin, menjaga, atau memutuskan hubungan intim mereka dengan pihak lain. Orang-orang membentuk keluarga mereka melalui interaksi sosial. Komunikasi memungkinkan pasangan kencan untuk bertemu dan mengevaluasi status hubungan mereka. Ketiga, komunikasi keluarga mencerminkan hubungan antarpribadi di antara anggota keluarga. Dengan demikian, komunikasi ini menawarkan kepada para peneliti dan ahli teori cara untuk memprediksi kualitas dan jalannya hubungan keluarga.

Fitzpatrick dan kawan-kawan mengembangkan teori Pola Komunikasi Keluarga (Family Communication Patterns Theory). Teori ini mengasumsikan bahwa penciptaan realitas sosial bersama adalah fungsi dasar komunikasi keluarga. Keluarga menciptakan realitas bersama melalui dua perilaku komunikasi, yaitu percakapan dan orientasi konformitas. Pola komunikasi keluarga merupakan komunikasi yang berlangsung dalam keluarga, dimana sumbernya yaitu orangtua kepada anaknya maupun anak kepada orangtua yang memiliki pola-pola tertentu (A. Sari et al., 2010).

Berkenaan dengan teori ini Fitzpatrick (Azizah et al., 2017) mengategorikan empat tipe keluarga, yakni keluarga konsensual, keluarga pluralistik, keluarga protektif, dan keluarga laissez-faire. Pola komunikasi keluarga ini diasosiasikan dengan sejumlah proses dalam keluarga, seperti konflik, konfirmasi dan afeksi, ritual keluarga, serta pemahaman. Juga diasosiasikan dengan kegiatan anak, seperti pemahaman, komunikasi dengan pacar, ketabahan dan kesehatan fisik serta mental anak. Keluarga konsensual memiliki level orientasi percakapan dan konformitas tinggi yang dicirikan dengan keterbukaan antara orang tua dan anak. Orang tua mau mendengarkan anak dan sekaligus berusaha membujuk anak agar menuruti mereka. Keluarga pluralistik menekankan orientasi percakapan daripada konformitas. Dalam keluarga ini interaksi terbuka dan tidak dibatasi. Orang tua cenderung menerima pendapat anaknya yang mungkin berbeda dengan pendapatnya. Anak-anak belajar mandiri dan berkomunikasi secara persuasif. Berbeda dengan keluarga protektif yang menekankan pada konformitas daripada percakapan. Orang tua memiliki otoritas tinggi dan anak harus mematuhi aturan orang tua. Sebaliknya, pada keluarga laissez-faire orientasi percakapan dan konformitas rendah. Mereka jarang berkomunikasi, sehingga secara emosional hubungan orang tua dan anak tidak terlalu dekat.

Situasi kehidupan suatu keluarga tidak selamanya stabil. Terkadang muncul masalah yang dapat menimbulkan stress. Misalnya, ketika terjadi konflik kekerasan, perang, bencana alam yang dahsyat, atau kehilangan orang yang dicintai dalam keluarga. Untuk itu orang tua harus mempersiapkan anakanak agar mampu bertahan dalam menghadapinya dan mampu beradaptasi dengan situasi yang sulit. Keluarga sebagai unit integral dari masyarakat sangat penting dalam menentukan bagaimana masyarakat pulih setelah terjadinya peristiwa traumatik. Terlepas dari tingkat trauma, keluarga adalah inti dari semua penyembuhan karena efek trauma massal di seluruh masyarakat, generasi, dan waktu dapat dikurangi secara signifikan melalui penanganan yang tepat dalam keluarga.

Ketahanan (resiliensi) adalah kemampuan untuk beradaptasi secara positif ketika seseorang dihadapkan pada kesulitan atau stres (Mawarpury \& Mirza, 2017). Konstruk ketahanan keluarga menjelaskan situasi di mana keluarga yang menghadapi tingkat tinggi stres mampu mempertahankan fungsi yang sehat meskipun dampak negatif dari kesulitan muncul.

Keluarga memiliki peran penting dalam mengembangkan ketahanan anak untuk menghadapi problema kehidupan. Keluarga juga berperan dalam menciptakan stabilitas, pemeliharaan, kesetiaan dan dukungan bagi anggotanya (Herawati et al., 2020). Keluarga disebut juga sebagai tempat paling awal dan efektif dalam menjalankan fungsi pendidikan untuk menanamkan kejujuran, kedisiplinan, dan rasa tanggung jawab sebagai unsur dari karakter anak. Peran keluarga yang baik akan menjadi sebuat tempat yang tepat untuk perkembangan anggota keluarga secara wajar, sehingga membentuk sebuah keluarga yang harmonis dan bahagia (Marta et al., 2020). Untuk mewujudkan hal tersebut, diperlukan komunikasi partisipatif di dalam sebuah keluarga.

Komunikasi partisipatif merupakan suatu proses komunikasi yang terjadi secara dua arah atau dialogis, yang menghasilkan sebuah pemahaman yang sama terhadap pesan yang disampaikan (Satriani et al., 2011). Jika fungsi komunikasi keluarga tidak berjalan dengan baik, maka dapat tercipta stabilitas, pemeliharaan, kesetiaan dan dukungan bagi anggotanya. Jika fungsi keluarga tidak dilakukan dengan maksimal, maka akan timbul berbagai hal negatif bagi anggota keluarga atau masyarakat sekitanya. Jika fungsi keluarga berjalan baik, maka anggota keluarga akan dapat 
menyelesaikan masalah, saling mendukung, berkomunikasi efektif, dan menanggapi bersama tantangan yang dihadapi (Sari \& Monalisa, 2021).

Pada level individu keluarga memberikan anak dasar-dasar untuk menghadapi stres dan memulihkan keadaan. Secara khusus komunikasi orang tua-anak berperan penting dalam merancang respon-respon yang baik dalam menghadapi situasi-situasi yang dapat menimbulkan stres dan mengembangkan anak dalam merespon kesulitan. Pada level yang lebih luas sistem keluarga secara utuh dapat merespon trauma atau kesulitan hidup dengan cara yang dapat memperkuat atau melemahkan hubungan dalam keluarga. Dari sisi ini, ketahanan keluarha mengacu pada proses-proses yang dijalankan keluarga guna memfasilitasi adaptasi terhadap cobaan dan kesulitan hidup.

Ada yang berpendapat ketahanan sebagai karakteristik bawaan setiap individu (Luecken \& Gress, 2010) namun (Buzzanell, 2010) menjelaskan ketahanan sebagai kemampuan yang dapat dikembangkan melalui praktik dan pengalaman. Menurut (Theiss, 2018), terdapat dua teori yang menekankan pentingnya peran komunikasi orang tua dalam mengembangkan respon-respon perilaku dan emosional anak yang memfasilitasi ketahanan. Pertama teori pengelolaan emosi dari (Gottman et al., 1998) yang menekankan sifat-sifat komunikasi orang tua yang membentuk kemampuan anak untuk mengenali dan merespon pengalaman emosional mereka secara efektif. Kedua, teori (Baumrind, 1991) yang mengemukakan bahwa komunikasi orang tua yang responsif dapat meningkatkan pengelolaan emosi pada anak remaja, sedangkan komunikasi orang tua yang membatasi diasosiasikan dengan melemahnya pengelolaan emosi dan meningkatnya perilaku impulsif.

(Walsh, 2003) mengemukakan model ketahanan keluarga yang baik adalah yang mempunyai struktur yang mendorong fleksibilitas dan adaptasi, membangun keterhubungan, dan mobilitas sumber daya sosial serta ekonomi yang baik dalam keluarga. Komunikasi yang diwarnai dengan keterusterangan, perbincangan emosional yang terbuka, dan penyelesaian masalah yang kolaboratif merupakan ciri-ciri komunikasi keluarga tangguh.

Kekerasan berbasis gender online (KBGO) merupakan semua tindak kekerasan yang difasilitasi perangkat digital, bertujuan untuk membuat korbannya menderita, merasa tidak aman dan tidak nyaman, sehingga mengalami kerugian material dan bisa juga immaterial dikarenakan gender atau norma sosial yang dibebankan pada seseorang akibat alat kelamin yang dimiliki (United Nations, 1989).

Kekerasan yang terjadi di dunia maya ini berakar pada budaya patriarkhi. Dalam budaya patriarkhi laki-laki selalu dinomorsatukan, sehingga dalam relasi gender terjadi ketimpangan. Bentuk ketidaksetaraan ini bermacam-macam, seperti subordinasi, marjinalisasi, beban berlebih, dan stereotipe (Hatifah, 2015). Ketika terjadi kemajuan dibidang teknologi informasi dan segala hal beralih ke dunia digital, maka budaya patriarkhi ikut beralih ke dunia digital.

Bentuk-bentuk KBGO bervariasi, mulai dari doxing, penggalian data pribadi seseorang yang digunakan untuk tujuan jahat, seperti pelecehan dan intimidasi di dunia nyat, flaming, online shaming, dan ujaran kebencian. Flaming merupakan penyerangan oleh perseorangan melalui pesan pribadi yang berisi ancaman, hinaan, pelecehan, dan pengiriman video porno. Online shaming adalah tindakan penghinaan secara daring. Di sini pelaku menjelekkan seseorang dengan konten berisi hinaan, menjatuhkan nama orang, menyebar hoaks, dan ajakan melakukan sikap buruk terhadap seseorang secara beramai- ramai. Adapun ujaran kebencian adalah tindakan untuk membenci seseorang dengan target identitasnya diiringi tindak kekerasan.

\section{METODE PENELITIAN}

Meskipun penelitian tentang KBGO sudah banyak dilakukan, namun penelitian ini tetap penting mengingat kasus KBGO di Indonesia terus bertambah. Selain itu, penelitian tentang KBGO yang ada lebih berfokus pada jenis-jenis KBGO dan dampaknya, serta bentuk kampanye untuk mengatasinya. KBGO tidak menyasar pada fisik korban, namun secara psikis dampaknya lebih menyakitkan. Korban merasa dipermalukan, sehingga kepercayaan dirinya runtuh, merasa tersakiti sehingga menimbulkan stres, cemas, dan trauma serta merasa bersalah. Terkadang korban juga mengalami kerugian secara ekonomi karena ada kalanya pelaku melakukan kekerasan ini dengan motif memeras. Penelitian ini mengkaji pola komunikasi keluarga dan resiliensi pada korban KBGO. Kebaruan penelitian ini ada pada aspek komunikasi keluarga dan resiliensi yang belum dibahas dalam penelitian-penelitian sebelumnya. 
Penelitian ini juga mengaitkan hubungan korban KBGO dengan komunikasi keluarga dan resiliensi mengingat kedua komunikasi ini berperan penting bagi korban dalam menghadapi kasusnya. Penelitian ini menggunakan pendekatan kualitatif dengan jenis penelitian deskriptif. Partisipan penelitian terdiri atas lima orang yang semuanya adalah korban KBGO. Pengumpulan data dilakukan dengan pengamatan, wawancara mendalam, dan studi pustaka. Peneliti mengalami kesulitan di dalam mencari partisipan sekalipun di LBH APIK korbannya tercatat ratusan, namun ternyata banyak yang menarik laporan kasusnya, menolak diwawancara karena tidak ingin mengingat lagi kasusnya atau tidak mau kasusnya diketahui pihak lain. Untuk itu peneliti menghubungi P2TP2A Tangerang Selatan dan mendapatkan satu nama korban yang bersedia dihubungi. Partisipan lainnya peneliti peroleh melalui beberapa kenalan yang kebetulan berteman dengan korban KBGO. Kelima partisipan ini namanya disamarkan agar tidak dikenali oleh khalayak. Setiap subjek penelitian diberi nama abjad huruf Latin.

Peneliti mengumpulkan data dengan pengamatan, wawancara mendalam melalui Google meet, Facebook dan Whattsapp Group. Hal ini menjadi kelemahan dari penelitian ini. Peneliti tidak dapat mewawancarai mereka secara bertatap muka karena adanya pemberlakuan PPKM Level 2 sehubungan dengan pandemi Covid-19. Studi pustaka dilakukan dengan menelusuri bahan bacaan dari Internet, buku-buku, dan artikel di jurnal. Analisis data dilakukan dengan analisis model Miles dan Huberman. Analisis data ini dibagi dalam tiga tahap: kodifikasi data, penyajian data, dan penarikan kesimpulan (Afrizal, 2017). Metode yang digunakan fenomenologi. Penelitian dilakukan di Jakarta dan sekitarnya (Jabodetabek) selama enam bulan dari Februari-Agustus 2021.

\section{HASIL DAN PEMBAHASAN}

\section{Gambaran Umum Subjek Penelitian}

Partisipan penelitian ini terdiri atas lima orang. Usia mereka bervariasi. Ada yang sudah bekerja, ada pula yang masih kuliah semester 3 dan semester 7. Status perkawinan mereka juga tidak sama, ada yang sudah menikah, ada pula yang belum, ada pula yang berstatus janda. Gambaran umum partisipan penelitian dapat dilihat pada tabel berikut:

Tabel 1. Gambaran Umum Partisipan

\begin{tabular}{lllllll}
\hline & \multicolumn{1}{c}{ A } & \multicolumn{1}{c}{ B } & C & \multicolumn{1}{c}{ D } & E \\
\hline Usia (Tahun) & 19 & 37 & 27 & 32 & 21 \\
\hline Status & Lajang & $\begin{array}{l}\text { Orang tua } \\
\text { tunggal }\end{array}$ & Lajang & Menikah & Lajang \\
\hline Pendidikan & PT & SMK & PT & PT & PT \\
\hline Pekerjaan & Mahasiswa & Karyawan & Karyawan & Karyawan & Mahasiswa \\
\hline
\end{tabular}

Dari data di atas dapat dilihat bahwa usia partisipan bervariasi. Satu orang berusia 19 tahun, dua orang berusia 22 dan 27 tahun, dan 2 orang berusia 32 dan 37 tahun. Status mereka pun tidak sama. Ada tiga orang lajang dan satu orang yang sudah menikah dan satu, orang tua tunggal (bercerai). Kebanyakan partisipan berpendidikan hingga perguruan tinggi. Hanya satu yang lulusan sekolah menengah atas. Dua orang berstatus mahasiswa dan tiga orang sudah bekerja. Faktor demografi ini penting untuk diperhatikan dalam kaitannya dengan sikap mereka dalam menghadapi persoalan.

Belum terlindunginya data diri pengguna media sosial menyebabkan banyak orang, terutama perempuan dengan mudah dicuri data dirinya. Data diri ini kemudian dimanfaatkan oleh orang yang berniat jahat. Karena itu, setiap perempuan harus menjaga menjaga tubuh digitalnya agar tidak dimanfaatkan oleh orang jahat.

\section{Bentuk Kekerasan yang Dialami}

Bentuk-bentuk kekerasan yang dialami para korban dapat digambarkan pada tabel 2. Bentuk-bentuk KBGO yang dialami korban tampak beragam, Mulai dari foto-foto editan yang menampakkan korban bertelanjang, foto-foto yang diberi teks bahwa korban "mengiklankan" diri, foto-foto korban dengan busana minim disebar melalui e-mail, dikirim gambar porno, dan ancaman akan dilaporkan ke polisi karena cuitan korban di Twitter. Para korban umumnya tidak menyadari fotonya beredar di media Jurnal Komunikasi Pembangunan | Vol. 20(01) 2022 | 19 
sosial. Mereka baru mengetahui dari kawan atau follower-nya. Media yang digunakan pelaku bervariasi. Mulai dari e-mail, Twitter, Facebook, hingga Instagram. Pelaku memilih media sosial yang dimiliki korban. Lamanya waktu pelaku mengunggah foto korban juga bervariasi. Ada yang kurang dari seminggu, ada yang sekali kirim, namun ada pula yang lama dan sering.

Tabel 2. Bentuk KBGO dan Media Sosial yang Digunakan

\begin{tabular}{|c|c|c|c|c|}
\hline Nama & $\begin{array}{c}\text { Bentuk kekerasan } \\
\text { yang dialami }\end{array}$ & Perkiraan penyebab & Media Sosial & Durasi \\
\hline $\mathbf{A}$ & Foto diri tanpa busana & $\begin{array}{l}\text { Pernah berhubungan tidak } \\
\text { serius dengan laki-laki } \\
\text { yang dikenal melalui } \\
\text { Tinder (aplikasi dating) }\end{array}$ & $\begin{array}{l}\text { Instagram dan } \\
\text { Twitter }\end{array}$ & Seminggu \\
\hline \multirow[t]{2}{*}{$\mathbf{B}$} & $\begin{array}{l}\text { Foto diri dimuat dengan } \\
\text { keterangan: Saya budak } \\
\text { seks, siap melayani laki- laki. } \\
\text { Silakan hubungi no .... atau } \\
\text { datang langsung ke alamat .... }\end{array}$ & $\begin{array}{l}\text { Pergi meninggalkan suami } \\
\text { sirinya yang sering } \\
\text { melakukan KDRT }\end{array}$ & Facebook WA & $\begin{array}{l}\text { Sering terjadi } \\
\text { hingga } \\
\text { sekarang }\end{array}$ \\
\hline & $\begin{array}{l}\text { Foto-foto dengan pose untuk } \\
\text { konsumsi pribadi diunggah di } \\
\text { medsos. Selain kekerasan daring } \\
\text { juga kekerasan fisik, dan } \\
\text { nonfisik, seperti dijambak, } \\
\text { dipukul, diguyur air, } \\
\text { dibentak, dimaki-maki dan } \\
\text { diteror }\end{array}$ & & & \\
\hline $\mathrm{C}$ & $\begin{array}{l}\text { Mengalami doxing, data } \\
\text { pribadinya diunggah ke media } \\
\text { sosial tanpa persetujuan. } \\
\text { Foto-foto dengan pacarnya } \\
\text { diberi komentar: "Lumayan } \\
\text { cantic ya. Bisa dijemput } n i h ! \\
\text { Ancaman akan dilaporkan ke } \\
\text { polisi. }\end{array}$ & $\begin{array}{l}\text { Pada awal-awal pandemi } \\
\text { Covid- } 19 \text { ketika banyak } \\
\text { tenaga kesehatan gugur ia } \\
\text { mempertanyakan } \\
\text { kehadiran pemerintah } \\
\text { lewat cuitan Twitter }\end{array}$ & $\begin{array}{l}\text { Twitter } \\
\text { Instagram }\end{array}$ & $\begin{array}{l}\text { Kurang dari } \\
\text { sebulan }\end{array}$ \\
\hline $\bar{D}$ & $\begin{array}{l}\text { Foto-foto dengan busana } \\
\text { minimnya dikirim ke e-mail } \\
\text { fakultas. }\end{array}$ & $\begin{array}{l}\text { Memutuskan hubungan } \\
\text { dengan pacar }\end{array}$ & E-mail & Sekali kirim \\
\hline $\mathbf{E}$ & $\begin{array}{l}\text { Mendapat kiriman foto alat } \\
\text { kelamin laki-laki. }\end{array}$ & $\begin{array}{l}\text { Tidak mengetahui } \\
\text { penyebab pasti }\end{array}$ & IG & Beberapa kali \\
\hline
\end{tabular}

Para korban kebanyakan tidak dapat memprediksi siapa pelakunya. Mereka hanya memperkirakan dengan mengaitkan kejadian-kejadian sebelumnya. Seperti A yang sebelumnya pernah berhubungan tidak serius dengan laki-laki yang dikenalnya melalui aplikasi kencan daring (dating online). Karena ia tidak mau meneruskan hubungan, maka laki-laki itu marah dan mengunggah fotonya yang diedit menjadi tanpa busana. Begitu diberitahu temannya bahwa fotonya yang ditulisi dengan kata-kata kotor ada di medsos, B langsung menerka pelakunya adalah mantan suami sirinya. Menurut B, tidak ada orang lain yang mengetahui password media sosialnya kecuali mantannya. Karena itu dia langsung menelepon dan memintanya untuk menghapus. Sang mantan tidak mengaku dan tidak juga menghapusnya.

Selain melakukan KBGO, mantan B juga meneror secara langsung dengan mendatangi tempat kerja B. Gara-garanya pelaku menelepon $\mathrm{B}$, namun tidak diangkat. Laki-laki berperawakan tambun itu memaki-maki $\mathrm{B}$ yang juga diancam akan disantet. Berbeda dengan $\mathrm{B}, \mathrm{C}$ tidak mengetahui pasti pelakunya, namun ia menduga buzzer yang marah karena tokoh idolanya dikritik. 
Sama seperti B, D juga langsung menebak pelakunya adalah mantan pacarnya yang baru saja diputus. Hanya mantan pacar inilah yang tahu password e-mail-nya. E semula tidak punya gambaran tentang pelakunya, namun atas dorongan pacarnya dia mencoba memancing pelaku agar membuka jati dirinya. Usahanya berhasil. Berikut penuturan E:

"Saya desak dia untuk ngaku siapa, tapi dia menolak. Terus saja saya pancing untuk ngobrol di WA. Begitu dia menelepon, muncullah nomornya yang kebetulan saya simpan. Ternyata dia teman satu komunitas di kampus. Gak nyangka banget. Anaknya baik, rajin shalat dan aktif di organisasi. Dia mengaku berbuat begitu, karena mendapat tantangan dari temannya," (E, komunikasi pribadi pada 26/11/2021)

\section{Dampak yang Dirasakan}

Mengenai dampak yang dirasakan para korban dapat dilihat pada tabel 3. Dari tabel 3 di bawah tampak bahwa dampak KBGO sangat membekas pada diri para korban. Mulai dari malu, sedih, takut membuka hp, merasa bersalah, merasa dikhianati, takut dipenjara, stres, pikiran terganggu, hingga trauma. Sekalipun demikian, tidak semua korban bersedia menceritakannya pada orang tua atau keluarga. Sikap korban ini sejalan dengan model pola komunikasi keluarga yang dikemukakan Fitzpatrick dalam teorinya.

Tabel 3. Dampak yang dirasakan korban

\begin{tabular}{|c|c|c|c|}
\hline Nama & Dampak yang dirasakan & Keterbukaan pada & Respon yang didapat \\
\hline $\mathbf{A}$ & $\begin{array}{l}\text { Malu, sedih, pikiran } \\
\text { terganggu, stres, takut } \\
\text { membuka akun media } \\
\text { sosialnya untuk beberapa } \\
\text { lama }\end{array}$ & $\begin{array}{l}\text { Hanya pada teman-teman } \\
\text { dekat. } \\
\text { Ia merasa kurang dekat } \\
\text { dengan orang tua }\end{array}$ & $\begin{array}{l}\text { Dukungan moril berupa nasihat- } \\
\text { nasihat, hiburan dengan diajak } \\
\text { ngobrol santai }\end{array}$ \\
\hline B & $\begin{array}{l}\text { Syok, malu, merasa } \\
\text { dikhianati, disakiti, trauma, } \\
\text { takut. }\end{array}$ & $\begin{array}{l}\text { Teman-teman dekat. } \\
\text { Alasan: sejak kecil terbiasa } \\
\text { menyelesaikan masalah } \\
\text { sendiri. Juga karena tidak ingin } \\
\text { membebani pikiran orang tua. }\end{array}$ & Dukungan moril dan nasihat \\
\hline $\mathbf{C}$ & $\begin{array}{l}\text { Semula santai, tetapi ketika } \\
\text { diancam mau dilaporkan ke } \\
\text { polisi ketakutannya } \\
\text { memuncak, karena khawatir } \\
\text { dipenjarakan. }\end{array}$ & $\begin{array}{l}\text { Orang tua, pacar, dan teman- } \\
\text { teman aktivis }\end{array}$ & $\begin{array}{l}\text { Ibu mendukung sepenuhnya. } \\
\text { Demikian pula pacarnya sangat } \\
\text { mengayomi. Teman- teman } \\
\text { mencarikan strategi untuk } \\
\text { menghadapi jika kasus dibawa } \\
\text { ke ranah hukum. }\end{array}$ \\
\hline $\mathbf{D}$ & $\begin{array}{l}\text { Malu, sakit hati, merasa } \\
\text { dikhianati }\end{array}$ & $\begin{array}{l}\text { Kedua orangtua dan saudara- } \\
\text { saudara kandung. }\end{array}$ & $\begin{array}{l}\text { Perhatian, dukungan moril. } \\
\text { Orang tua mengupaykan } \\
\text { membawa kasus ini ke ranah } \\
\text { hukum, }\end{array}$ \\
\hline $\mathbf{E}$ & Syok, takut, malu & $\begin{array}{l}\text { Orang tua, pacar, dan } \\
\text { kakak tingkat. }\end{array}$ & $\begin{array}{l}\text { Semua memberikan dukungan } \\
\text { yang kuat, pendampingan, dan } \\
\text { menghibur. }\end{array}$ \\
\hline
\end{tabular}

Dua partisipan merasa lebih nyaman membicarakan masalahnya dengan teman dekat dan sama sekali menutupi persoalannya ini. Hal ini dilatarbelakangi oleh kondisi keluarga mereka. Partisipan A (komunikasi pribadi dengan A pada 21/11/2021) mengaku cenderung lebih suka memendam sendiri kasus-kasus yang menimpanya. Sewaktu A masih balita, ayah dan ibunya bercerai. Sebagai orang tua tunggal ibunya sibuk bekerja dan tidak banyak berkomunikasi dengan A. Ia lebih banyak membuat aturan-aturan yang harus dipatuhi A. Sebagai anak A tergolong penurut. Dia menuruti semua aturan ibunya, karena takut jika menolak akan disuruh tinggal dengan ayahnya yang sudah menikah lagi. Jika ada persoalan dia biasa mencurahkan isi hatinya pada sahabat sebayanya. Ketika bertumbuh remaja kebiasaan seperti ini terus terbawa. Di kampus dia memiliki teman kelompok yang baik dan selalu mendukungnya. Ketika menghadapi persoalan ini pun ia banyak mendapat dukungan dari temannya. 
Perlahan-lahan dia mulai bangkit. Dia mulai berani menggunakan lagi telepon genggamnya untuk keperluan kuliah dan berhubungan dengan teman-temannya melalui WA.

B yang sudah pernah berumah tangga dan menjadi orang tua tunggal juga cenderung menutupi kasusnya ini. Ia enggan bercerita pada keluarganya. Sejak dulu orang tuanya jarang mengajaknya berkomunikasi. Mereka juga tidak suka ikut campur dengan urusan anak-anaknya. Mereka menganggap semua urusan anaknya merupakan privasi masing-masing. Seperti dalam pola keluarga laissez-fare B menganggap berbincang dengan keluarga kurang berguna:

"Paling-paling bapak-ibu akan mengatakan, 'Kamu sudah dewasa, semua masalahmu harus bisa kamu selesaikan sendiri.' Apalagi mereka dulu tidak merestui pernikahan saya yang kedua ini. Jadi, kalau saya mengadu pasti mereka menyalahkan saya. Selain itu, saya kasihan pada orang tua saya sudah berumur," (komunikasi pribadi dengan B pada 29/3/2021;10/7/2021)

Dalam menghadapi kasusnya ini B hanya bercerita pada sahabatnya. Ia kemudian disarankan untuk melapor ke P2TP2A. Di sana ia berkonsultasi dan mendapat pendampingan. Setelah itu ia melapor ke polisi. Pada awalnya, teman-temannya bersemangat mendukung, namun ketika pihak kepolisian meminta mereka menjadi saksi, satu per satu mundur. B merasa sangat sedih dan kecewa. Selain itu ia juga dimintai uang senilai 5 juta rupiah agar perkaranya bisa disidangkan. Karena tidak sanggup memenuhi syarat ini, ia pun tidak melanjutkan perkaranya. Kasusnya mandeg hingga sekarang. Mantan suami sirinya pun masih terus menerornya dan menunggah foto B dengan tulisan yang menyakitkan.

Partisipan $\mathrm{C}$ merasa beruntung karena meskipun tidak mengetahui pelakunya, ia bisa menceritakan kasusnya pada ibu, pacar, dan teman-temannya sesama aktivis. C tergolong dekat sekali dengan ibunya yang berstatus janda setelah bercerai dengan ayah $\mathrm{C}$ sejak $\mathrm{C}$ berusia 15 tahun. Meski sibuk bekerja ibu $\mathrm{C}$ menjalin komunikasi yang baik dan terbuka dengan anaknya. Ibu $\mathrm{C}$ menceritakan semua persoalan yang dihadapinya. Keterbukaan sang ibu mendorong $\mathrm{C}$ bersikap sama. Setiap $\mathrm{C}$ menghadapi persoalan, ibunya selalu mendukung secara moral tanpa harus ikut campur menyelesaikan.

"Waktu saya ceritakan kasus ini, Mama malah bilang, 'Hadapi saja, ngapain takut? Bukannya dulu kamu biasa mendampingi klien di pengadilan?' Saya tertegun Mama bilang begitu. Dia gak marah atau menyalahkan saya," (komunikasi pribadi dengan C, 26/7/2021)

$\mathrm{C}$ juga bercerita pada pacar dan teman- temannya sesama aktivis. $\mathrm{C}$ serius membicarakan masalahnya dengan teman-temannya setelah pelaku mengancam akan melaporkannya ke polisi. Saat itu dia merasa dalam bahaya, meski pacar dan teman-temannya meyakinkan bahwa kasusnya tergolong ringan. C baru merasa tenang setelah mereka membeberkan sejumlah langkah alternatif jika kasus ini berlanjut.

Sama seperti C, D juga langsung menceritakan kasusnya kepada kedua orang tuanya. Awalnya ia takut dimarahi, namun ternyata tidak. Ayahnya diam-diam malah berkonsultasi pada temannya yang polisi. Ia pun disarankan melaporkan pelaku ke divisi Cyber Crime di Polda Metro Jaya. Dengan gerak cepat sang ayah mempersiapkan segala sesuatunya hingga akhirnya pelaku dimejahijaukan. Sementara itu D terus didampingi keluarganya agar tetap tegar menghadapi kasus yang baru sekali ini terjadi dalam keluarganya. Saat itu D sedang menyusun skripsi. Ketika persidangan berlangsung D hadir didampingi seluruh anggota keluarganya. Hakim memvonis pelaku enam bulan potong masa tahanan. Mendengar putusan ini $\mathrm{D}$ tak kuasa menahan air matanya. Ia mencium tangan kedua orang tuanya. Berikut penuturan D yang di dalam keluarganya membudayakan saling keterbukaan satu sama lain:

"Waktu saya bercerita Bapak Ibu sama sekali tidak menyalahkan saya, meskipun saya menyadari bahwa tindakan saya salah. Mereka sepenuhnya mendukung. Mereka hanya menasihati agar ke depan saya lebih berhati-hati dan tidak boleh terlalu percaya pada orang lain," (komunikasi pribadi dengan D pada, 28/7/2021)

Dalam keluarga E hubungan antara orang tua dan anak sangat baik. Kedua orang tua E meskipun sibuk berdagang namun selalu menyediakan waktu untuk mendengarkan keluh kesah anak-anaknya. Hanya, menurut E, ayahnya keras, sehingga dia agak mikir-mikir jika hendak menceritakan kasusnya. Ibunya pun pada awal mendengarkan cerita $\mathrm{E}$ agak emosi dan berkeinginan untuk menghajar pelaku. Pacar E yang juga mengetahui kasus ini bersikap sangat tenang sambil memikirkan jalan keluar yang tepat.

E pun tidak tinggal diam. Dia segera mengirim pesan kepada seluruh anggota komunitasnya agar waspada jika menerima pesan dari orang yang menyembunyikan identitasnya. Dia lalu berkoordinasi 
dengan kakak tingkatnya yang menjadi ketua komunitas. Mereka berdua kemudian bersepakat menjumpai pelaku. Ketika bertemu pelaku berisikap biasa seperti tidak terjadi ada-apa. Dalam pertemuan ini pelaku mengaku bahwa dia melakukan hal itu untuk melepaskan perasaan tertekannya. Waktu dia kecil dokter mendiagnosis bahwa dia mengidap sakit jantung. Dia harus terus-menerus minum obat. Orang tuanya selalu melarangnya melakukan berbagai hal. Pengekangan ini membuat pelaku mengalami stres dan rendah diri. Ketika beranjak remaja dia mulai melampiaskan perasaan tertekannya dengan mengirimkan gambar-gambar porno ke teman-temannya. Seusai melakukannya dia merasa lega. Senior E yang menyita telepon genggam pelaku mendapati sekira seratusan gambar sudah berhasil disebarkan. Penerimanya sebagian adalah teman-teman mahasiswa sekampus dari berbagai angkatan.

Sekalipun E telah dilecehkan, namun E merasa kasihan pada pelaku. Alih-alih ingin menghukum pelaku, dia justru ingin membantunya agar berkonsultasi dengan psikolog.

"Kesalahannya perlu dihukum. Tetapi hukuman itu tidak menjamin dia berhenti melakukan kebiasaan buruknya itu. Karena itu dia perlu diterapi," ujar E (Komunikasi pribadi dengan E pada 26/11/2021). Sejak mengetahui identitas pelakunya E langsung memberitahukan pada semua anggota komunitas yang perempuan, agar waspada terhadap pesan-pesan langsung (direct message) di akun media sosialnya. Ternyata beberapa anggota sudah lebih dulu menerima kiriman foto porno tersebut, namun mereka diam tidak ada yang berani melapor. Mereka hanya memblokir akun pelaku. Melalui WAG yang dibuatnya, E berusaha untuk mengajak para anggotanya agar tegar dan berani menghadapi kekerasan berbasis gender ini.

"Saya ajak teman-teman korban untuk berani bersuara demi memperoleh keadilan. Siapa pun yang melakukan pelecehan seksual seperti ini harus dikenai sanksi yang setimpal," tegas E yang mengajak teman-temannya untuk membicarakan kasus ini dengan pemimpin fakultas.

Dari pemaparan di atas tampak bahwa peran komunikasi keluarga sangat penting di dalam menghadapi persoalan anggota keluarga, terutama kasus KBGO. Keluarga dengan pola komunikasi konsensual seperti yang dimiliki partisipan D mampu menyelesaikan masalah dengan baik. Orang tua D bersedia mendengarkan kasus anaknya dengan baik tanpa menyalahkan, namun di sisi lain mereka mencoba menanamkan kepercayaan yang diyakininya pada anak. Hal ini tampak ketika sang ayah berusaha membawa kasus ini ke ranah hukum. Partisipan A dan B yang memiliki pola komunikasi laissez-faire menghadapi masalah ini tanpa meminta dukungan dari pihak orang tua. Mereka cenderung menceritakan permasalahannya pada teman dekat. Mereka menganggap percakapan dengan keluarga kurang bermakna. Partisipan C dan E memiliki pola pluralistik. Mereka sangat terbuka pada orang tua, termasuk dalam ketika mengalami kasus KBGO. Orang tua kedua partisipan pun mendengarkan dengan penuh perhatian sekaligus memberikan dukungan. Kendati demikian ketika $\mathrm{C}$ berusaha untuk meminta bantuan teman-temannya, ibunya tidak melarang meskipun hal ini berbeda dengan keyakinannya bahwa $\mathrm{C}$ mampu menghadapinya. Demikian pula dengan E ketika berbeda pendapat dengan ibunya dalam menyikapi pelaku, ibunya bisa memahami. Seperti dikemukakan Theiss, keluarga juga memiliki peran penting dalam pengembangan ketahanan seseorang dalam menghadapi masalah atau kesulitan. Pada tingkat individu anak mendapat dasar-dasar berperilaku dan kemampuannya menghadapi permasalahan yang tidak terduga dari keluarga. Melalui komunikasi dengan orang tuanya seorang anak akan belajar merespon trauma atau kesulitan yang dihadapinya. Komunikasi ini juga memfasilitasi adaptasi anak dalam menghadapi cobaan dan kesulitan.

Jika dikaitkan dengan temuan di atas, tampak bahwa pola komunikasi yang dianut oleh keluarga partisipan ikut menentukan derajat ketahanannya di dalam menghadapi masalah. Masing-masing partisipan memiliki ketahanan yang berbeda. Pada partisipan A, dia sempat mengalami stres dan trauma untuk menggunakan telepon genggam. Berkat dukungan dari teman-teman kuliahnya dia perlahan bisa pulih. Sebagai anak yang dibesarkan orang tua tunggal dia jarang berkomunikasi dengan ibunya yang sibuk mencari nafkah. Ia terbiasa memendam permasalahan dan hanya mau terbuka pada teman dekatnya yang sebaya.

B tampak memiliki resiliensi yang cukup meskipun sempat mengalami syok dan trauma. Ia dibesarkan dalam keluarga dengan pola komunikasi laissez-faire. Semua hal harus dihadapi sendiri. C yang sejak kecil dibiasakan berkomunikasi secara terbuka dengan ibunya dalam menghadapi kasus ini resiliensinya cukup baik. Respon ibunya yang bersifat menguatkan dapat membantunya meningkatkan ketahanannya. Demikian pula yang terjadi pada D dan E. 
Resiliensi yang baik yang dialami D dan E sejalan dengan apa yang dikemukakan Baumrind dan Walsh dalam teorinya tentang struktur keluarga dan resiliensi anggota keluarga dalam menghadapi masalah. Baik keluarga D maupun E memiliki respon yang baik terhadap keluhan atau permasalahan yang dikemukakan anggota keluarga. Mereka mau mendengarkan permasalahan yang dihadapi anggota keluarga tanpa emosi bahkan dapat memberikan solusi yang bijak. Respon yang positif ini dapat membantu korban berpikir dengan jernih dan mengambil langkah-langkah yang tepat bagi penyelesaian masalahnya. Dukungan yang positif dari keluarga memungkinkan seseorang memiliki ketegaran dalam menghadapi dan menyelesaikan masalahnya. Pendampingan terhadap korban KBGO tidak cukup hanya melibatkan pihak berwajib dan psikolog. Peran keluarga dalam mendampingi korban justru menjadi hal yang sangat penting dalam mengembalikan mental korban. Membangun komunikasi keluarga yang baik merupakan satu hal yang perlu dilakukan oleh setiap keluarga untuk dapat mengantisipasi berbagai macam permasalahan yang menimpa anggotanya.

Kendati demikian untuk mewujudkan komunikasi keluarga yang baik bukan hal yang mudah. Hasil ini mendukung penelitian (Herawati et al., 2020) yang menemukan bahwa terdapat beberapa faktor yang mempengaruhi keberfungsian peran keluarga dalam mewujudkan keharmonisan hubungan antaranggota keluarga, kehangatan, dan dukungan antaranggota keluarga, yaitu faktor ekonomi, demografi, usia, dan budaya.

Komunikasi yang baik dengan orang tua dan respon positif orang tuanya dapat meningkatkan resiliensi korban dalam menghadapi cobaan ini. D yang tegar di pengadilan dan E yang berani mengajak korban-korban lain bersuara menyiratkan resiliensi mereka di dalam menghadapi kasus KBGO.

Selama ini riset yang membahas KBGO (Hayati, 2021); (Putri, 2020); (Risya et al., 2021) berhenti pada identifikasi kasus dan bentuk-bentuk kekerasannya, sedangkan penelitian ini mengaitkan KBGO dengan peran komunikasi keluarga yang pada akhirnya membentuk resiliensi pada anak. Dengan demikian, ketika dia mengalami kasus kekerasan seperti KBGO, mentalnya cukup kuat bahkan korban berani berbicara dan melawan pelaku. Dari kasus-kasus yang dikaji tampak bahwa untuk menghentikan atau meminimalkan KBGO diperlukan keberanian korban. Keberanian ini bisa muncul dengan dukungan keluarga yang bersikap terbuka dan mau mendengarkan keluhan korban, serta kesediaan mendampingi korban untuk melapor pada pihak yang berwajib. Penelitian ini juga menemukan bahwa dukungan teman dekat dapat berdampak positif pada korban yang semula mengalami trauma terhadap penggunaan media sosial. Lain halnya dengan korban yang tidak mendapat dukungan dari keluarga, penderitaannya menjadi lebih berat, karena harus memikul sendiri masalahnya yang tidak kunjung putus.

\section{KESIMPULAN}

Berdasarkan hasil temuan dan pembahasan di atas, peneliti menyimpulkan beberapa hal yaitu hadirnya media sosial yang difasilitasi Internet ternyata merupakan wilayah rawan bagi perempuan. Semakin banyak jumlah perempuan yang memanfaatkan media sosial, semakin terbuka kemungkinan mereka mengalami KBGO. Kekerasan yang semula ada di dunia nyata kini berpindah tempat ke dunia maya. KBGO membuat perempuan korban kehilangan haknya untuk merasa aman dan nyaman. Mereka menderita dan merugi, baik material maupun immaterial.

Dalam menghadapi kasus KBGO, peran komunikasi keluarga dan komunikasi resiliensi sangat penting. Empat pola komunikasi keluarga, seperti pola komunikasi konsensual, pluralistik, protektif, dan laissez-faire berhubungan erat dengan kesediaan korban untuk mengungkap masalahnya pada keluarga. Masing-masing pola komunikasi keluarga membentuk ketahanan (resiliensi) seorang anak dalam menghadapi kesulitan hidup. Pola keluarga konsensual di mana komunikasi anak dan orang tua lebih terbuka memungkinkan setiap anggota keluarga memiliki resiliensi yang baik. Ketika anak menjadi korban KBGO berkomunikasi secara terbuka dengan orang tua menjadi kekuatan baginya dalam menghadapi kekerasan. Korban merasa mendapat dukungan dari orang-orang di sekitarnya.

Tingkat resiliensi korban KBGO sangat dipengaruhi oleh respon keluarga terhadap permasalahan yang dihadapi korban. Respon yang baik dan memihak korban menjadikannya lebih berani menghadapi permasalahan bahkan sampai ke jalur hukum. Selain dari keluarga, dukungan positif dari lingkungan pertemanan atau komunitas tempat korban berada juga menjadi kekuatan bagi korban untuk melawan tindak kekerasan. Pola komunikasi konsensual yang memungkinkan adanya keterbukaan komunikasi 
antara anak dan orang tua merupakan pilihan terbaik. Keterbukaan komunikasi juga sangat bermanfaat bagi terbentuknya resiliensi anak, sehingga ketika menghadapi kasus-kasus kekerasan, seperti KBGO mereka dapat menghadapinya dengan tenang dan tegar.

Setiap keluarga diharapkan dapat menerapkan pola komunikasi konsensual yang memungkinkan adanya keterbukaan komunikasi antara anak dan orang tua. Keterbukaan komunikasi sangat bermanfaat bagi terbentuknya resiliensi anak, sehingga ketika menghadapi kasus-kasus kekerasan, seperti KBGO mereka dapat menghadapinya dengan tegar.

\section{DAFTAR PUSTAKA}

Afrizal. (2017). Metode Penelitian Kualitatif: Sebuah Upaya Mendukung Penggunaan Penelitian Kualitatif dalam Berbagai Disiplin (Cet.Ke-4). Rajawali Pers.

Al-Ubaidah, M. T. (2021, January 21). Kekerasan Berbasis Gender Online (KBGO). Kumparan.com. https://kumparan.com/mohammadtetraalubaidah/kekerasan-berbasis-gender-online-kbgo1v16FRfXjzk/2

Azizah, M., Hubeis, A. V. S., \& Wibowo, C. T. (2017). Pola Komunikasi Keluarga Wanita Pekerja Malam terhadap Pengasuhan Anak (Studi Kasus: Pada Pegawai Wanita di Lapas Wanita Kelas II A Bandarlampung). Jurnal Komunikasi Pembangunan, 15(1), 107-122. https://doi.org/10.46937/15201722780

Baumrind, D. (1991). The Influence of Parenting Style on Adolescent Competence and Substance Use. The Journal of Early Adolescence, 11(1). https://doi.org/10.1177/0272431691111004

Buzzanell, P. M. (2010). Resilience: Talking, resisting, and imagining new normalcies into being. Journal of Communication, 60(1). https://doi.org/10.1111/j.1460-2466.2009.01469.x

Gottman, J., Declaire, J., \& Goleman, D. (1998). Raising An Emotionally Intelligent Child The Heart of Parenting. In Simon Schuster Paperbacks.

Gunby, C., Isham, L., Damery, S., Taylor, J., \& Bradbury-Jones, C. (2020). Sexual violence and covid-19: All silent on the home front. Journal of Gender-Based Violence, 4(3).

https://doi.org/10.1332/239868020X15984631696329

Hatifah, R. D. (2015). Pengaruh Relasi Gender dan Pengambilan Keputusan Terhadap Kinerja Guru Sekolah Menengah Pertama Negeri (SMP Negeri) di Kecamatan Bekasi Selatan Kota Bekasi. Jurnal Manajemen Pendidikan, 6(2). https://doi.org/10.21009/jmp.06201

Hayati, N. (2021). Media Sosial dan Kekerasan Berbasis Gender Online Selama Pandemi Covid-19. Humaya: Jurnal Hukum, Humaniora, Masyarakat, Dan Budaya, 1(1). https://doi.org/10.33830/humaya.v1i1.1858.2021

Herawati, T., Pranaji, D. K., Pujihasvuty, R., \& Latifah, E. W. (2020). Faktor-Faktor yang Memengaruhi Pelaksanaan Fungsi Keluarga di Indonesia. Jurnal Ilmu Keluarga Dan Konsumen, 13(3). https://doi.org/10.24156/jikk.2020.13.3.213

Hikmawati, P. (2021). Pengaturan Kekerasan Berbasis Gender Online: Perspektif Ius Constitutum dan Ius Constituendum. Negara Hukum, 12(1).

Hubeis, A. V. S., \& Mulyandari, R. S. H. (2010). Analisis Teori Performance dan Positioning dalam Komunikasi Pembangunan Berwawasan Gender. Jurnal Komunikasi Pembangunan, 8(1), 245267. https://doi.org/10.29244/jurnalkmp.8.1.\%p

Kemen PPPA RI. (2020). Panduan Perlindungan Perempuan Dari Kekerasan Berbasis Gender Selama Pandemi Diluncurkan. Kementerian Perbedayaan Perempuan Dan Perlindungan Anak Republik Indonesia (Kemen PPPA). https://www.kemenpppa.go.id/index.php/page/read/29/2992/panduan-perlindungan-perempuandari-kekerasan-berbasis-gender-selama-pandemi-diluncurkan

Kemen PPPA RI. (2021). Kemen PPA Dorong Literasi Digital Untuk Cegah Kekerasan Berbasis Gender Online (KBGO) Selama Masa Pandemi. Kementerian Perbedayaan Perempuan Dan Perlindungan Anak Republik Indonesia (Kemen PPPA). https://www.kemenpppa.go.id/index.php/page/read/29/3215/kemen-pppa-dorong-literasi-digital- 
untuk-cegah-kekerasan-berbasis-gender-online-kbgo-selama-masa-pandemi

Littlejohn, S. W., \& Foss, K. A. (2016). Ensiklopedia Teori Komunikasi (1st ed.). Kencana.

Luecken, L. J., \& Gress, J. L. (2010). Early Adversity and Resilience In Emerging Adulthood. Handbook of Adult Resilience., 2010.

Marta, R. F., Fernando, J., \& Kurniawati, L. S. M. W. (2020). Tinjauan Peran Komunikasi Keluarga Pada Kinerja Public Relations Melalui Konten Laman Resmi Media Daring KPPPA. Jurnal Komunikasi Pembangunan, 18(01), 30-42.

Mawarpury, M., \& Mirza, M. (2017). Resiliensi Dalam Keluarga: Perspektif Psikologi. Psikoislamedia : Jurnal Psikologi, 2(1). https://doi.org/10.22373/psikoislamedia.v2i1.1829

Nasrullah, R. (2018). Media Sosial: Perspektif Komunikasi, Budaya, dan Sosioteknologi (N. S. Nurbaya (ed.); Cet.Ke-5). Simbiosa Rekatama Media.

Nyhlén, S., \& Nygren, K. G. (2019). 'It's about gender equality and all that stuff...': Enacting policies on gender-based violence into everyday preventive work in rural Sweden. Journal of GenderBased Violence, 3(3). https://doi.org/10.1332/239868019X15627570242841

Putri, T. A. (2020). Fenomena Kekerasan Berbasis Gender Online Di Kalangan Mahasiswi Universitas Pendidikan Indonesia. Universitas Pendidikan Indonesia. repository.upi.edu

Risya, J., Prameswari, C., Jacomina, D., \& Hehanussa, A. (2021). Kekerasan Berbasis Gender Di Media Sosial. PAMALI: Pattimura MagisterLaw Review, l(1).

Riyanto, A. D. (2020). Hootsuite (We are Social): Indonesian Digital Report 2020. Global Digital Insights. https://datareportal.com/reports/digital-2020-indonesia

SAFEnet. (2019). Memahami dan Menyikapi Kekerasan Berbasis Gender Online: Sebuah Panduan. Southeast Asia Freedom of Expression Network, 20. https://id.safenet.or.id/wpcontent/uploads/2019/11/Panduan-KBGO-v2.pdf

Sari, A., Hubeis, A., Mangkuprawira, S., \& Saleh, A. (2010). Pengaruh Pola Komunikasi Keluarga Dalam Fungsi Sosialisasi Keluarga Terhadap Perkembangan Anak. Jurnal Komunikasi Pembangunan, 8(2), 245186. https://doi.org/10.29244/jurnalkmp.8.2.

Sari, M. ., \& Monalisa, A. (2021). Psychological well-being karyawan studi literatur. Syntax Idea, 3(1), 161-170. https://doi.org/https://doi.org/10.36418/syntax-idea.v3i1.863

Sari, N. (2021). Studi tentang kekerasan berbasis gender online. Jurnal Dewantara, XI(01).

Satriani, I., Muljono, P., \& Lumintang, R. W. . (2011). Komunikasi Partisipatif Pada Program Pos Pemberdayaan Keluarga (Studi Kasus di RW 05 Kelurahan Situgede, Kecamatan Bogor Barat, Kota Bogor). Jurnal Komunikasi Pembangunan, 9(2). https://doi.org/https://doi.org/10.46937/920119042

Statistika. (2020). Berapa Usia Mayoritas Pengguna Media Sosial di Indonesia? Katadata.Co.Id. https://databoks.katadata.co.id/datapublish/2020/11/23/berapa-usia-mayoritas-pengguna-mediasosial-di-indonesia\#

Theiss, J. A. (2018). Family communication and resilience. Journal of Applied Communication Research, 46(1). https://doi.org/10.1080/00909882.2018.1426706

Vangelisti, A. L. (ed). (2004). Handbook of Family Communication. Lawrence Erlbaum Assosiates.

Walsh, F. (2003). Family resilience: A framework for clinical practice. Family Process, 42(1). https://doi.org/10.1111/j.1545-5300.2003.00001.x

Web Foundation. (2021). How Online Gender-Based Violence Affects The Safety of Young Women and Girls. World Wide Web Foundation. https://webfoundation.org/2021/03/how-online-genderbased-violence-affects-the-safety-of-young-women-and-girls/ 